\title{
Analysis of Cooperation and Motivation Nurse in Implentation Nursing of Family
}

\author{
Siti Nur Kholifah ${ }^{1}$, Nursalam $^{2}$, Meriyana $^{3}$, Ahsan $^{4}$, Minarti $^{5}$, Dwi Ananto Wibrata ${ }^{6}$, \\ Noer Saudah ${ }^{7}$ \\ ${ }^{1}$ Education Program Health Sciences Public Health Faculty Airlangga University, Indonesia \\ ${ }^{2}$ Department of Medical Surgical Nursing Airlangga University, Indonesia \\ ${ }^{3}$ Department of Nutrition Public Health Airlangga University, Indonesia \\ ${ }^{4}$ Department of Community Nursing Brawijaya University, Indonesia \\ ${ }^{5}$ Department of Community Nursing Politeknik Kesehatan Kemenkes Surabaya, Indonesia \\ ${ }^{6}$ Department of Medical Surgical Politeknik Kesehatan Kemenkes Surabaya, Indonesia \\ ${ }^{7}$ Department of Maternal Nursing STIKES Bina Sehat PPNI Mojokerto, Indonesia
}

\section{Article Info \\ Article history: \\ Received Jun 15, 2016 \\ Revised Aug 23, 2016 \\ Accepted Aug 26, 2016}

\section{Keyword:}

Cooperation

Motivation

Nursing of family

\begin{abstract}
Cooperation of nurses needed in helping to resolve the client's problem. Cooperation was an important element in developing quality of human resources and improving performance. The general objective of this study was to identify cooperation-relation nurse with motivation in implementing the family nursing care at Surabaya city. The research method was analytical observational with cross sectional approach. The population of this study used all nurses at local government clinic at Surabaya city, totaling 175 people. This study used 122 people for sampling. The Sampling technique used probability sampling. The research variables include the cooperation of nurses and motivation in implementing family nursing care. Instrument used questionnaire. Analysis of the data used to determine the relationship among variables is done by test-Spearman correlation. Limit the test of significance is 0.05 . The results of the research analysis shows that there is a relationship of cooperation with the motivation of nurses in implementing family nursing care $(\mathrm{p}=0.03)$. Suggestion is based on research that nurses should develop cooperative relationships in order to increase their motivation to carry out the nursing care of the family.
\end{abstract}

Copyright $@ 2016$ Institute of Advanced Engineering and Science. All rights reserved.

\section{Corresponding Author:}

Noer Saudah,

Department of Nursing Maternity, STIKES BINA SEHAT PPNI,

Indonesia.

Email: saudah_noer@yahoo.co.id

\section{INTRODUCTION}

Cooperation according to Herzberg's theory of motivation hygiene Herzburg is one of the custodian motivational factors. Herzburg stated that nurses will feel satisfied or dissatisfied in carrying out their job because of the movers and custodian motivational factor [1]. Nurses need strong motivation to do their job. Factors movers and custodians of motivation will determine an individual's performance. Some research results explain that the motivation affect performance of Nurse [2].

Motivation in implementing the family nursing care determines the quality of provided service and affects the achievement of the independence of the family in caring for sick family members. Nursing problem in the family is very complex, not only physical problem but also psychological problem and the influence of culture requires a special approach. The approach can be performed by nurses is collaboration with the team so that the problem can be resolved and encourage the achievement of independence in the 
family. There has never done research on the relationship between cooperation with the motivation of nurses in implementing the family nursing care. Research problem: How is the relationship between the cooperation of nurses with motivation in implementing family nursing care? The general objective of this study is to identify the relationship between the cooperation of nurses with motivation in implementing family nursing care at Surabaya city.

\section{RESEARCH METHOD}

The method used analytical observational with cross sectional approach. The population in this study is all nurses at local government clinic who are D III Nursing status of civil servants in the city of Surabaya, totaling 175 people, spread across 63 local government clinic throughout the Surabaya city. The minimum sample needs 122 people. The sampling technique is probability sampling using this type of simple random sampling. The research variables are the cooperation of nurses and nurse motivation in implementing family nursing care. Instrument research used questionnaire. The relationship between the dependent and independent variables is done with the Spearman correlation test. Limit test of significance used was 0.05 so when $\mathrm{p}<0.05$, statistically significant calculations mean that there is a relationship between the dependent and independent variables.

\section{RESULTS AND ANALYSIS}

General data presented in this chapter are the characteristics include characteristics of age, gender, marital status, education level and work experience. Table 1 shows that the characteristics of age, the majority nurses at local government clinic between the ages of 25-40 years. The gender characteristics at Local government clinic are mostly women. The majority nurses at Local government clinic are married. Characteristics education level of nurse, majority is D III Nursing. Work experience of at Local government clinic nurses is mostly 1-15 years.

Table 1. Characteristics Nurse at local government clinic Surabaya in 2015

\begin{tabular}{|c|c|c|c|}
\hline No & $\begin{array}{l}\text { Characteristics Nurse at Local } \\
\text { government clinic }\end{array}$ & Total & Percentage \\
\hline & Age & & \\
\hline \multirow[t]{3}{*}{1} & Age $25-40$ years & 112 & 91.80 \\
\hline & Age $41-56$ years & 10 & 8.20 \\
\hline & Gender & & \\
\hline \multirow[t]{2}{*}{2} & Man & 40 & 32.80 \\
\hline & Woman & 82 & 67.20 \\
\hline \multirow[t]{4}{*}{3} & Marital Status & & \\
\hline & Married & 116 & 95.08 \\
\hline & Unmarried & 6 & 4.20 \\
\hline & Education level & & \\
\hline \multirow[t]{3}{*}{4} & D III Nursing & 107 & 87.70 \\
\hline & S1 Ners & 15 & 12.30 \\
\hline & Work Experience & & \\
\hline \multirow[t]{2}{*}{5} & $1-15$ years & 110 & 90.16 \\
\hline & $16-31$ years & 12 & 9.84 \\
\hline
\end{tabular}

The results of the analysis of the cooperation of nurses and motivation in implementing family nursing care at Surabaya city. The results of each analysis will be described as follows:

\subsection{Cooperation of nurses in implementing family nursing care}

Table 2 shows that nurse cooperation and team is mostly at "sufficient category".

Table 2. Cooperation in Implementing Family Nursing Care at Surabaya City in 2015

\begin{tabular}{ccc}
\hline Cooperation & Total & Percentage \\
\hline Good & 29 & 23.77 \\
Sufficient & 52 & 42.62 \\
Lack & 41 & 33.61 \\
Total & 122 & 100 \\
\hline
\end{tabular}




\subsection{Nurse motivation in implementing family nursing care}

Table 3 explains that the motivation of nurses in implementing the family nursing services is mostly at "sufficient category". Table 4 shows that the crosses table above shows the relationship between the cooperation of nurses with motivation in implementing family nursing care. Results showed that nurses who have good cooperation majority had sufficient motivation. Nurses who have sufficient cooperation had sufficient motivation too. Nurses who have a lack of cooperation also had significant motivation in implementing family nursing care.

Table 3. Nurse Motivation in Implementing Family Nursing Care at Surabaya City in 2015

\begin{tabular}{ccc}
\hline Motivation & Frequency & Percentage \\
\hline Good & 13 & 10.7 \\
Sufficient & 99 & 81.1 \\
Lack & 10 & 8.2 \\
Total & 122 & 100 \\
\hline
\end{tabular}

Table 4. The Relationship between Cooperation and nurse Motivation in Implementing Family Nursing Care at Surabaya city, 2015

\begin{tabular}{cccccc}
\hline Cooperation & Good & $\begin{array}{c}\text { Motivation } \\
\text { Sufficient }\end{array}$ & Lack & Total & \multirow{2}{*}{ P Value } \\
\hline Good & $8(27.6 \%)$ & $20(69 \%)$ & $1(3.4 \%)$ & 29 & \\
Sufficient & $4(7.7 \%)$ & $44(84.6 \%)$ & $4(7.7 \%)$ & 52 & 0.03 \\
Lack & $1(2.4 \%)$ & $35(85.4 \%)$ & $5(12.2 \%)$ & 41 & \\
Total & 13 & 99 & 10 & 122 & \\
\hline
\end{tabular}

The result showed that motivation variable and cooperation carried out by nurses are largely at sufficient category. It shows that there is a relationship between cooperation and nurse motivation in implementing family nursing care [3] explains that nurses need someone else as the work team. Relationships with other health team nurses as midwives, nutritionists, environmental sanitation personnel in implementing family nursing services affect the team's motivation. Integration of family nursing care with other health services at home support the health service policy in the community to solve the client's health problems and his family [4].

Nurse motivation is interpreted as psychological characteristics that give contribution to the level of commitment in carrying out its duties [5]. Motivation in implementing family nursing care determines the quality of provided services. The stronger is the motivation of nurses, the stronger is the desire to provide nursing services to the family [1]. In accordance with Herzberg motivation theory that explains that the interpersonal relationships in this cooperation is a factor that affects the motivation externally.

Cooperation among professionals in the health sector will enhance the benefit for patients and families. Health team collaboration by ANA 1992 in [6] is a working relationship that has a shared responsibility with other health care providers in the delivery (supply) of nursing care to clients. Cooperation of health team is activity aimed to strengthen the relationship among the different health professions and help to solve problem of health clients well. In addition, it can improve performance in various aspects related to the health care system. All health professionals are required to have good qualifications in their respective fields so as to reduce the human error factor in delivering health services.

Cooperation and coordination among professionals include shared goals, shared knowledge and mutual respect [7]. Collaboration of health team consists of various health professions such as doctors, nurses, psychiatrists, nutritionists, pharmaceutical, health educators, and social workers. The main objective of the collaboration of health teams is providing appropriate services, by an appropriate health team, at the right time and in the right place. The important elements in the health team collaboration are communication skills, mutual respect, trust, and decision making processes. The concept of collaborative health team itself is a concept of complex cooperation relationships. And it requires the exchange of knowledge oriented health services for clients [6].

Johnson stated that the recommendation for inter-professional collaboration is to pay attention on values and practical ethics of each profession, sensitivity to patients at the health center, paying attention to cultural diversity and differences among the teams, noticed a unique role and responsibilities among the teams, communication with patients, families and communities and other health care teams, working effectively in a variety of roles [8].

Type of collaboration of health care team, including: (1) Fully Integrated Major is a collaboration in which every part of the team has the responsibility and the same contribution for the same purpose, (2) 
Partially Integrated Major, is a form of collaboration that each member of the team has a different responsibility but still have a common purpose, (3) joint Program Office is a form of collaboration which does not have a common goal but has an employment relationship that is profitable when done jointly, (4) joint Partnership with Affiliated Programming is a collaboration to provide services and generally does not look for profit among one and the others, (5) Joint Partnership for Issue Advocacy is a form of collaboration which has a long-term mission but with short-term goals, but should not form a new team.

Family Health Team describes about 12 types of team collaborations [9]. They are the primary reproductive care (for example, pre-natal, obstetric, postpartum, and newborn care); primary mental health care, primary palliative care; in-home/facility usage to support services; care coordination/care navigation; patient education and prevention; chronic diabetes disease management program, heart disease, obesity, arthritis, asthma, and depression; health promotion and disease prevention; health of the mother/child; occupational health; elderly health; addiction treatment; rehabilitation services; and parenting.

The principles of the health care team collaboration are: (1) patient-centered care is principle which is more priority to the interests and needs of the patients. Patients and families are giving a decision in the matter of health, (2) recognition of patient-physician relationship is trust and behave in accordance with the code of conduct and respect one another, (3) Physician as the clinical leader is a good leader in making decision, especially in case of an emergency nature, (4) mutual respect and trust, is trust by understanding the division of tasks and each competence.

Establishing and maintaining team collaboration of health services are essential in order to provide health care services to clients optimally. Naylor explains that the health team cooperation will improve the quality of service to client [10]. Some ways which can be done to establish and maintain health care team collaboration is by making sure that all team members can meet regularly to discuss the next agenda, all the medical team involved in any plans, to know each other among the team members to get good contribution, the communication must be established well and routine, mutual trust, support and respect, conduct regular evaluation to improve the situation in the future and appreciate every opinion and contribution of all team members. There are problems in how health care professional communicate and interact with each other. Lack interprofessional collaboration can negatively affect to delivery of health services. Interprofessional collaboration based intervention are strategies put into place in health care setting to improve work interaction and process [11].

Health team collaboration is important because each health personnel has the knowledge, skill, ability, competency, and experience. Gittel describes that the sharing of knowledge and skills may occur during the process of collaboration. This condition can increase the motivation of nurses in the work [7]. Nurses will get additional knowledge and skill when collaborating with other health teams. Professional working in interprofessional teams allow sharing of expertise and perspective to form maintaining and individual's health and improving outcomes [12]. The addition of this capability is an opportunity to advance for the nurse. Opportunity to progress according to Herzberg's theory is a motivator for someone to do a job. Complexity of health problems in the family encourages nurses to cooperate not only with the health team (Traffic program) but also with the relevant sectors such as local government officials, health workers and other community organizations.

\section{CONCLUSION}

Nurse Cooperation is associated with motivation in implementing family nursing care at the health center of Surabaya City. Based on the research, it can be suggested nurses should enhance both cooperation across programs and across sectors so that it will increase the ability and will increase the motivation to carry out the family nursing care.

\section{REFERENCES}

[1] Wibowo, "Management of Work Performance,” Jakarta, Rajawali Pres, pp. 7-196, 2014.

[2] Canadian Medical Association, "Putting patient first: patient-centered collaborative care, a discussion paper, 2007.

[3] Widiastutik, "Factor of Influence to Work Motivation Nurse on Nursing Hospital Psychiatric Surakarta," Jurnal Ilmu Keperawatan Indonesia, vol/issue: 1(1), 2012.

[4] Oandasan, et al., "Teamwork in Healthcare: Promoting Effective Teamwork in Healthcare in Canada," 2006.

[5] Nursalam, "Manajement of Nursing, Applied of Professional Nursing Practice," Jakarta, Salemba Medika, 2011.

[6] Kozier, Erb, Berman, Snyder, "Hand Book Fundamental of Nursing: Concept, Process, and Practice. Edision 7," Jakarta, EGC, 2010.

[7] H. J. Gittel, M. Godfrey, J. Thistletwaite, "Interprofessional collaborative practice and relational coordination: Improving healthcare through relationships," Journal of Interprofessional Care, vol/issue: 27(3), pp. 210-213, 2013. 
[8] J. E. Johnson, "Working together in the Best Interest of Patients," Journal of The American Board of Family Medicine, vol/issue: 26(3), pp. 241-243, 2011.

[9] Family Health Teams, "Guide to Collaborative Team Practice," Canada, Ontario, 2005.

[10] M. D. Naylor, "Interprofessional collaboration and the future of health care," Healthcom Media, vol/issue: 6(6), pp. $1-5,2011$.

[11] M. Zwarenstein, J. Goldman, S. Reeves, "Interprofessional collaboration: effect of practice-based interventions on professional practice and health care outcomes," Cochrane Library, 2009. http: onlinelibrary.wiley.com.

[12] R. D. Beidges, et al., "Interprofessional collaboration: three best practice models of interprofessional education," Medical Education Online Journal, vol. 16, pp. 1-3, 2011.

\section{BIOGRAPHIES OF AUTHORS}

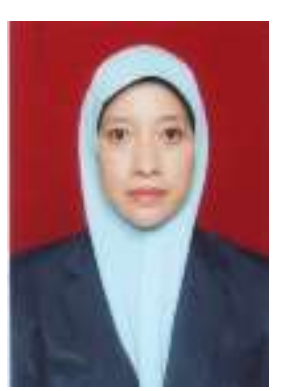

Name: Siti Nur Kholifah, SKM, M.Kep.Sp.Kom. HP: 08121782930. S3 Doctoral Education Program Health Sciences Public Health Faculty Airlangga University. Address: Bronggalan II F/38 Surabaya. Email: kholifah_stp@yahoo.co.id

Higher Education:

1. Master or Nursing Specialist Community Health Nursing Indonesia University, 2007

2. Bachelor of Nursing Airlangga University, 2002

3. Bachelor of Public Health Airlangga University, 1998

4. Diploma III in Nursing Academy Islamic Hospital Surabaya, 1994 Organization and Working Experiences:

1. Lecture in Nursing Diploma III Sutopo Health Polytechnic Ministry of Health in Surabaya (since 1997-Now)

2. Head of IPKKI (The Association of Indonesian Community Health Nurses) East Java 2013-2018 Publication: Accredited journal and international $=5$

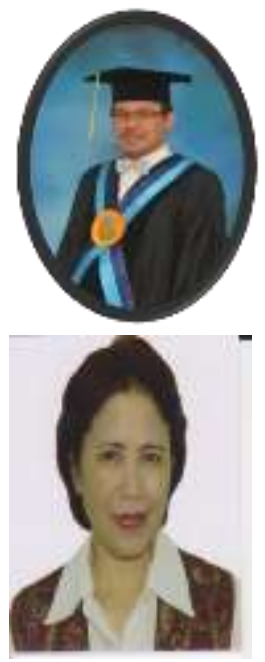

He is Prof. Dr. Nursalam, M.Nurs (Hons). He is a Professor in Nursing, Airlangga University and he is my promotor in doctoral programme. He was born on 25 Desember 1966 in Kediri. He was studied in Med. Surgical Nursing, Lambton College, Sarnia Ontario Canada, on 1991. He completed Master of Nursing (Coursework), Univ. Wollongong, NSW, Australia on 1996. He continued Honours Master of Nursing, University of Wollongong, New South Wales, Australia, on 1997 and he complete Doctor, Model of Nursing Care for HIV-AIDS, Post graduate Programme Airlangga University on 2005. This year, He is a dean on faculty of nursing Airlangga University. He is a head PPNI east Java 2015-2020.

She is Dr. Merryana Adriani, S.KM., M.Kes. She is a Lecture in Public Health, Airlangga University and she is my first co-promotor in doctoral programme. She was studied Doctor Postgraduate Programme Airlangga University on 2009. Before she studied Master of Nutritional Public Health Airlangga University on 2000. She is Head of Division Academic, Faculty of Public Health Airlangga University (2011 - now)

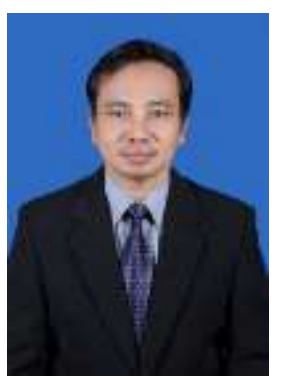

Name: Dr. Ahsan, SKp, M.Kes. HP : 08125293950. Lecture in Nursing, brawijaya University. Address: Pasrseh Jaya no 4C Rt 03 Rw 02 Kelurahan Bumiayu Kec. Kedung Kandang Kota Malang. E-mail: ahsanfkub@yahoo.com.

Higher Education:

1. Doctor of Public Health Science Airlangga University, 2013

2. Master or Public Health Airlangga University, 2002

3. Bachelor of Nursing Padjajaran University, 1998

Organization and Working Experiences

1. Lecturer in Nursing School Ministry of Health in Malang (1983-1998)

2. Lecturer in Dilpoma III Maternity Ministry of Health in Malang (1998-2001)

3. Lecturer in School of Nursing, Medicine Faculty/Faculty of Nursing, Brawijaya University (Since 2001-Now)

4. Head Nursing Department, Medicine Faculty Brawijaya University (2016-Now)

Publication: Accredited journal and international $=10$ 


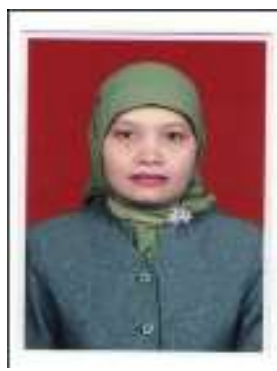

Name: Minarti, M.Kep.Sp.Kom. HP: 082139493067. Lecture in Nursing Diploma III Sutopo Health Polytechnic Ministry of Health in Surabaya. Address: Kali Kepiting Jaya X/1 Surabaya. Email: minartiivan@gmail.com.

Higher Education:

1. Master or Nursing Specialist Community Health Nursing Indonesia University, 2007

2. Bachelor of Nursing Airlangga University, 2002

3. Diploma III in Nursing Academy Soetomo Surabaya, 1989

Organization and Working Experiences:

1. Lecture in Nursing Diploma III Sutopo Health Polytechnic Ministry of Health in Surabaya (since 1991-Now)

Publication: Accredited journal and international=2

Name: Dr. Dwi Ananto Wibrata, SST, M.Kes. HP: 0811315467. Lecture in Nursing Diploma III

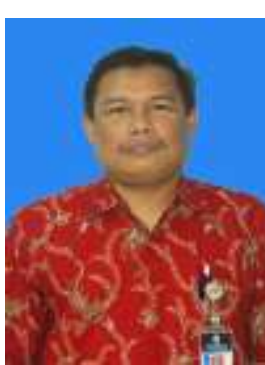

Soetomo Health Polytechnic Ministry of Health in Surabaya. Address: Bronggalan II F/38 Surabaya.

Email: wibrata_daw@yahoo.co.id.

Higher Education :

1. Doctor of Public Health Science Airlangga University, 2014

2. Master or Public Health Gajah Mada University, 2004

3. Bachelor of Nursing Airlangga University, 2000

4. Diploma III in Nursing Academy Islamic Hospital Surabaya, 1994

Organization and Working Experiences:

1. Lecture in Nursing Diploma III Anesthesia in Surabaya (since 1994-2007)

2. Lecture in Nursing Diploma III Soetomo Health Polytechnic Health Department in Surabaya (since 2007-Now)

Publication: Accredited journal and international=2

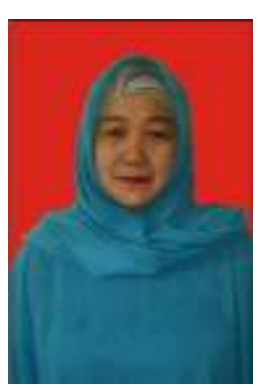

I am Noer Saudah. I were born on 15 September 1971 in Mojokerto. I studied in Bachelor of Nursing, Faculty of Medicine Airlangga University on 2002. I completed my master in medicine faculty Airlangga University on 2008. This year, I finished doctoral postgraduate programme public health Airlangga University. I have many interests in maternity of nursing and reproduction of health. I am a lecture on STIKes Bina Sehat PPNI Kabupaten Mojokerto 